\title{
PERBANDINGAN KELENGKAPAN PENGISIAN REKAM MEDIS KONVENSIONAL DAN PROTOTIPE INTEGRATED ELECTRONIC SURGICAL REPORT (IESR)
}

\author{
Nyoman Dwi Maha Udiyana ${ }^{*}$, Ede Surya Darmawan², Cicilya Candi ${ }^{3}$ \\ ${ }^{1}$ Mahasiswa Manajemen Administrasi Rumah Sakit Fakultas Kesehatan Masyarakat Universitas Indonesia \\ ${ }^{2,3}$ Departemen Administrasi dan Kebijakan Kesehatan Fakultas Kesehatan Masyarakat Universitas Indonesia \\ Alamat korespondensi: *dr_dwimu@yahoo.co.id
}

\begin{abstract}
Abstrak
Pemanfaatan Rekam Medis Elektronik (EMR) merupakan implementasi dari perkembangan teknologi informasi dan komunikasi di bidang kesehatan. EMR meningkatkan kualitas dan dokumentasi rekam medis. Prototipe Integrated Electronic Surgical Report (IESR) merupakan pengembangan EMR yang menekankan pada kelengkapan laporan operasi, memungkinkan ahli bedah melengkapi rekam medis berbasis android secara efisien. Penelitian ini merupakan penelitian mixed method, menggunakan studi kualitatif untuk mendapatkan umpan balik dari pengguna IESR, dan studi analitik cross sectional untuk mengetahui perbandingan kelengkapan pengisian rekam medis antara Integrated Electronic Surgical Report (IESR) dan rekam medis konvensional di RS Sultan Imanuddin. Data sekunder diperoleh 31 sampel rekam medis dari departemen rekam medis pada bulan oktober sampai desember 2020. Hasil analisis bivariat dengan uji Mann_Whitney didapatkan nilai p=0,061. Ada beberapa aspek positif yang diperoleh antara lain: kesederhanaan, durasi yang singkat, dan efisiensi dalam pemenuhan rekam medis dengan menggunakan IESR. Namun tidak terdapat perbedaan yang signifikan antara pemanfaatan prototipe IESR dan rekam medis konvensional dalam hal pemenuhan kelengkapan rekam medis pasien ruang bedah.
\end{abstract}

Kata Kunci: Rekam Medis Elektronik, Integrated Electronic Surgical Report (IESR), Kelengkapan

\begin{abstract}
The utilisation of Electronic Medical Record (EMR) is an implementation of information and communication technological development in healthcare. EMR improve quality and documentation of medical record. Integrated Electronic Surgical Report (IESR) prototype is an EMR development that concerned on surgical report fulfillment , allows the surgeon fullfill an android based medical record efficiently. This research is mixed method study, using qualitative study to get feedback from the IESR user, and a cross sectional analytic study to know the comparison of medical records filling completeness between Integrated Electronic Surgical Report (IESR) and conventional medical records at Sultan Imanuddin hospital. Secondary data of 31 medical record sample from medical record department in october until december 2020 was obtained. Bivariate analysis result using Mann_Whitney test showed $\mathrm{p}=0.061$. There are few positive aspect including: simplicity, short duration and efficiency in medical record fulfilment using IESR. But there is no significant difference between IESR prototype utilisation and conventional medical record in term completeness fulfilment of surgical ward patients medical record.
\end{abstract}

Keywords: Electronic Medical Record, Integrated Electronic Surgical Report, completeness 


\section{PENDAHULUAN}

Perkembangan teknologi informasi dan komunikasi telah merambah ke sektor kesehatan. Adopsi rekam medis elektronik menjadi semakin meluas. Hal tersebut didukung dengan adanya tuntutan masyarakat akan peningkatan kualitas pelayanan kesehatan. Pemanfaatan teknologi ini digunakan antara lain untuk mengembangkan sistem informasi dengan menggunakan dukungan sistem komputerisasi. Menurut Stengel et al, 2004, kualitas dokumentasi rekam medis dapat ditingkatkan secara signifikan dengan menggunakan rekam medis berbantuan komputer. Sistem ini juga menyediakan kemampuan untuk mengubah diagnosis ke sistem ICD (Stengel, Bauwens, Walter, Köpfer, \& Ekkernkamp, 2004). Rekam medis elektronik portabel dapat membantu meningkatkan pendokumentasian rekam medis dibandingkan dengan rekam medis konvensional (Wu \& Straus, 2006).

PermenkesNo.269/Menkes/Per/III/20

08 menyatakan bahwa setiap dokter atau dokter gigi harus membuat rekam medis dalam melaksanakan praktik kedokteran. (Kemenkes RI, 2008b). Tanpa terkecuali terkait pengisian laporan pembedahan oleh ahli bedah.

Menurut pusat data dan informasi Kementerian Kesehatan RI tahun 2018, rasio sebaran dokter bedah di Indonesia adalah 2/100.000 penduduk (Kemenkes RI, 2019). Dokter bedah memiliki tugas yang beragam dalam prakteknya, seperti melakukan pelayanan klinis kepada pasien di poliklinik, IGD, di bangsal bedah maupun di ruang operasi. Selain itu, melengkapi rekam medis juga menjadi tugas yang wajib dilakukan oleh para dokter. Oleh karena itu diperlukan suatu metode yang efisien dan terintegrasi dalam pengisian rekam medis, khususnya laporan bedah.

Berdasarkan pantauan, setelah menjalani pembedahan, minimal harus diisi delapan bentuk rekam medis, termasuk laporan pembedahan. Pada penelitian sebelumnya penulis membuat prototipe Integrated Electronic Surgical Report (IESR) melalui metode design thinking. Ini menekankan pengisian laporan bedah yang dibantu komputer tablet. Output dari IESR adalah delapan komponen rekam medis, termasuk laporan pembedahan yang harus diselesaikan secara cepat dan akurat oleh dokter bedah. Penggunaan aplikasi ini diharapkan dapat menciptakan efisiensi waktu, meningkatkan kualitas rekam medis. Ini memungkinkan para ahli bedah untuk menghemat waktu dan dapat melakukan layanan lainnya. Jika rekam medis dilengkapi dengan baik, rekam medis dapat dikembalikan tepat waktu ke departemen rekam medis. Diharapkan dapat meningkatkan profil kualitas pelayanan rekam medis pasien di bangsal bedah (Udiyana NDM \& Darmawan ES, 2020).

Tujuan dari penelitian ini adalah: 1) memulai tahap pengujian aplikasi prototipe Integrated Electronic Surgical Report (IESR) yang dikembangkan melalui metode design thinking, 2) membandingkan antara penggunaan aplikasi IESR dengan rekam medis konvensional ditinjau dari kelengkapan rekam medis pasien di bangsal bedah RSUD Sultan Imanuddin pada bulan Oktober hingga Desember 2020.

\section{METODE PENELITIAN}

Desain penelitian ini adalah mixed method. Metode kualitatif dimulai dengan wawancara dan mendapatkan tanggapan dari pengguna prototipe IESR. Studi analitik cross sectional sebagai metode kuantitatif dengan membandingkan penggunaan IESR dengan rekam medis konvensional dalam hal kelengkapan rekam medis. Data sekunder diperoleh dari 31 rekam medis di bagian Rekam Medis RS Sultan Imanuddin.

Prototipe Integrated Electronic Surgical Report (IESR) berbasis Android menggunakan jaringan internal rumah sakit, dan dapat dipasang di perangkat ponsel atau komputer tablet. Aplikasi IESR kemudian dihubungkan ke server komputer untuk penyimpanan data. Perancangan dibuat berdasarkan algoritma dan diagram alir yang serupa dengan setiap tahapan pengisian rekam 
medis (Udiyana NDM \& Darmawan ES, 2020).

\section{HASIL PENELITIAN}

Data diinput sesuai dengan sel data yang tersedia. Prototipe IESR menyediakan menu template tahapan operasi, yang dapat disesuaikan oleh operator sesuai permintaan. Output IESR terdiri dari delapan form output rekam medis termasuk form laporan pembedahan. IESR juga menyediakan file pdf yang dapat dicetak. Dari 31 rekam medis konvensional, 23 rekam medis lengkap dan 8 tidak lengkap. Dari 31 rekam medis yang diisi dengan prototipe IESR, 26 rekam medis lengkap dan 5 tidak lengkap. Data dianalisis menggunakan software statistik komputer. Analisis bivariat uji Mann-Whitney menunjukkan $\mathrm{p}=0,061 \quad(\mathrm{p}>0,005)$. Terdapat perbedaan antara jumlah rekam medis lengkap yang menggunakan IESR dibandingkan rekam medis konvensional, meskipun secara statistik tidak signifikan.

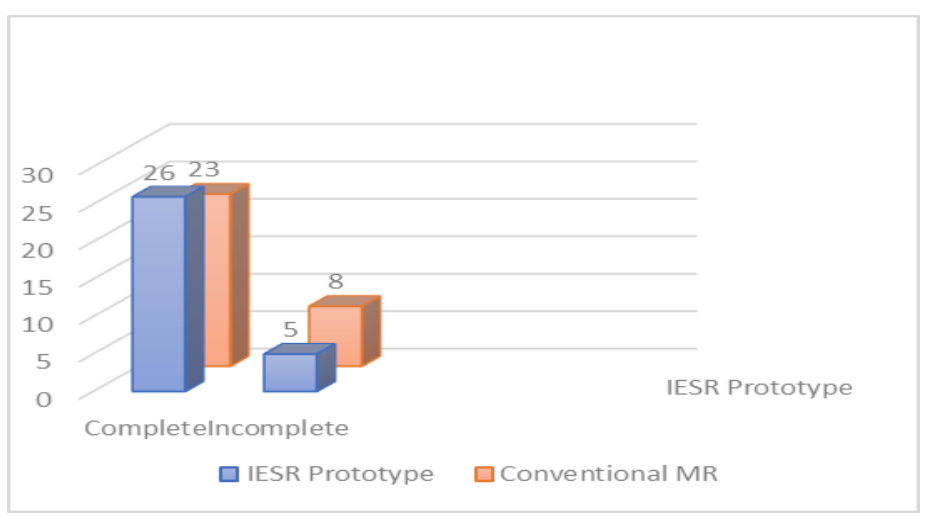

Gambar 1. Perbandingan Kelengkapan Pengisian Rekam Medis antara Rekam Medis Konvensional dengan Pengisian Rekam Medis IESR

Delapan pengguna memberikan masukan tentang penggunaan IESR. Menurut pengguna, penggunaan prototipe IESR dalam proses pengisian rekam medis menunjukkan kesederhanaan $(71,4 \%)$, durasi yang singkat $(75 \%)$ dan efisiensi $(85,7 \%)$ dalam pemenuhan rekam medis.

\section{PEMBAHASAN}

Rekam medis elektronik (EMR) telah banyak diadopsi di negara-negara Asia, termasuk Indonesia. EMR adalah metode terkomputerisasi untuk mengumpulkan, menyimpan dan mengirimkan data rekam medis (Ventura et al., 2011). EMR memiliki berbagai keunggulan antara lain kualitas rekam medis yang lebih baik, mudah dilacak, mudah digunakan, dan data yang mudah digunakan (Basjaruddin, NC; Kuspriyanto, Rakhman, E; Renardi, 2017). Kualitas dokumentasi rekam medis dapat ditingkatkan secara signifikan dengan menggunakan rekam medis berbantuan komputer (Stengel et al., 2004). Kualitas dokumentasi rekam medis dapat ditingkatkan dengan rekam medis elektronik portabel dibandingkan rekam medis konvensional.

Prototipe Integrated Electronic Surgical Report (IESR) yang dibuat pada penelitian sebelumnya merupakan rekam medis berbantuan komputer berbasis android. Program ini dapat diinstal pada perangkat ponsel, serta komputer tablet dan terhubung ke database ICD 9 dan ICD 10 (Stengel et al., 2004; Udiyana NDM \& Darmawan ES, 2020). Prototipe IESR dapat menyimpan dan menampilkan data template dari langkah operasi sesuai dengan masukan yang dimasukkan sebelumnya oleh ahli bedah. Output IESR terdiri dari delapan form output 
rekam medis termasuk form laporan pembedahan. Dapat diunduh ke dalam file pdf untuk dicetak lebih lanjut dan ditandatangani oleh dokter bedah (Udiyana NDM \& Darmawan ES, 2020).

Pedoman Standar Pelayanan Minimal (SPM) Rumah Sakit menyatakan bahwa indikator kelengkapan pengisian rekam medis 24 jam setelah pelayanan ideal mencapai $100 \%$ (Kemenkes RI, 2008a). Namun secara deskriptif berdasarkan data tabulasi silang setelah penggunaan IESR, masih terdapat rekam medis yang kurang lengkap yang dapat disebabkan oleh berbagai faktor termasuk faktor manusia atau desain IESR. Prototipe IESR masih perlu lebih ditingkatkan melalui metode design thinking. Bazzano et al (2017) mengemukakan bahwa metode design thinking berguna untuk meningkatkan inovasi yang ada (Bazzano, Martin, Hicks, Faughnan, \& Murphy, 2017).

Analisis bivariat uji Mann Whitney menunjukkan $\mathrm{p}=0,061$, hal ini menunjukkan tidak ada perbedaan yang signifikan antara IESR dibandingkan rekam medis konvensional dalam hal kelengkapan rekam medis. Hal tersebut mungkin disebabkan oleh desain IESR yang masih berupa prototipe yang belum diformat sebagai required filed yang pada pengisian sel data. Sehingga, masih ada kemungkinan operator melewatkan sel data yang kosong dalam proses pengisian. Namun dari aspek lain, penggunaan aplikasi IESR memungkinkan dokter bedah mengisi asesmen pasien yang dapat diubah menjadi pengkodean ICD 10 dan ICD 9. Hal ini didukung oleh penelitian yang dilakukan oleh Stangel et al (2004) yang memungkinkan penulisan asesmen pasien yang benar disertai dengan kemampuan untuk mengubah diagnosis menjadi sistem pengkodean ICD (Stengel et al., 2004).

Desain aplikasi IESR generasi selanjutnya masih perlu ditingkatkan. Hal ini dapat dicapai dengan penerapan proses mikro dan makro model pemikiran desain (Brown \& Wyatt, 2010; Muratovski, 2017) Pertimbangan pertama adalah mengubah pengaturan IESR yang mengharuskan operator untuk memenuhi semua sel data.
Untuk meningkatkan fungsi prototipe IESR akan dikembangkan lebih lanjut dengan menambahkan fitur pencatatan jadwal operasi pasien pra operasi, sehingga memudahkan operator dalam menginformasikan perkiraan jadwal operasi bagi pasien yang membutuhkan penjadwalan operasi.

\section{SIMPULAN DAN SARAN}

Ada beberapa aspek positif antara lain: kesederhanaan, durasi yang singkat dan efisiensi dalam pemenuhan rekam medis dengan menggunakan IESR. Sedangkan tidak terdapat perbedaan yang signifikan antara kegunaan prototipe aplikasi IESR dan rekam medis konvensional dalam hal kelengkapan pengisian rekam medis. Berdasarkan temuan ini, perlu adanya upaya pengembangan IESR yang terintegrasi dengan beberapa subsistem pelayanan di rumah sakit, khususnya RS. Sultan Imanuddin Pangkalan Bun dan juga melengkapi fitur-fitur sesuai kebutuhan pengguna, dalam hal ini adalah dokter bedah.

\section{UCAPAN TERIMAKASIH}

Terima kasih khusus kepada Bapak DR. Ede Surya Darmawan, SKM, MDM selaku dosen dan pembimbing akademik dalam penelitian ini, yang turut berkontribusi dalam proses penulisan makalah ini. Terima kasih kepada Ibu Cicilya Candi, SKM, MKM selaku dosen pembimbing yang turut berkontribusi dalam proses penulisan skripsi ini. Berkat program Hibah PUTI UI sebagai sumber pendanaan dalam penelitian ini.

\section{DAFTAR PUSTAKA}

Basjaruddin,NC; Kuspriyanto, Rakhman,E; Renardi, M. (2017). Pengembangan Rekam Medis Elektronik Berbasis Near Field Communication (NFC). Prosiding Saintiks FTIK UNIKOM. Retrieved from http://prosidingsaintiks.ftik.unikom.ac.id/jurnal/peng embangan-rekam-medis.3o

Bazzano, A. N., Martin, J., Hicks, E., Faughnan, M., \& Murphy, L. (2017). 
Human-centred design in global health: A scoping review of applications and contexts. PloS One, 12(11), e0186744. Retrieved from https://journals.plos.org/plosone/artic le/file?id=10.1371/journal.pone.0186 $744 \&$ type $=$ printable

Brown, T., \& Wyatt, J. (2010). Design thinking for social innovation. Development Outreach, 12(1), 29-43.

Kemenkes RI. (2008a). Permankes No. 129/Menkes/SK/II/2008, tentang Standar Pelayanan Minimal Rumah Sakit. Retrieved from http://manajemenrumahsakit.net/wpcontent/uploads/2012/08/PMK-No129-tahun-2008-tengan-SPM-RSlengkap.pdf

Kemenkes RI. (2008b). Permenkes RI. No 269/Menkes/Per/III/2008 tentang Rekam Medis. (p. 7). p. 7. Retrieved from

http://pelayanan.jakarta.go.id/downlo $\mathrm{ad} /$ regulasi/peraturan-menteri-

kesehatan-nomor-269-tentangrekam-medis.pdf

Kemenkes RI. (2019). Profil Kesehatan Indonesia 2018 (R. Y. B. H. Kurniawan, Ed.). Retrieved from https://pusdatin.kemkes.go.id/folder/ view/01/structure-publikasi-datapusat-data-dan-informasi.html Muratovski, G. (2017). Towards EvidenceBased Research and Cross-
Disciplinary Design Practice. In Creativity, Design Thinking and Interdisciplinarity (pp. 3-15). Retrieved from https://link.springer.com/chapter/10. 1007/978-981-10-7524-7_1

Stengel, D., Bauwens, K., Walter, M., Köpfer, T., \& Ekkernkamp, A. (2004). Comparison of handheld computer-assisted and conventional paper chart documentation of medical records: a randomized, controlled trial. JBJS, 86(3), 553-560.

Udiyana NDM, \& Darmawan ES. (2020). Implementasi Model Design Thinking dalam Perancangan Prototipe Integrated Electronic Surgical Report (IESR) di RSUD Sultan Imanuddin pangkalan Bun. Universitas Indonesia, Depok.

Ventura, M. L., Battan, A. M., Zorloni, C., Abbiati, L., Colombo, M., Farina, S., \& Tagliabue, P. (2011). The electronic medical record: pros and cons. The Journal of Maternal-Fetal \& Neonatal Medicine, 24(sup1), 163166.

Wu, R. C., \& Straus, S. E. (2006). Evidence for handheld electronic medical records in improving care: a systematic review. BMC Medical Informatics and Decision Making, $6(1), 1-5$. 